\title{
Nodulation and Development of Soybean Submitted to Inoculation With Bradyrhizobium japonicum and Phosphorus Doses
}

\author{
Erica Chaves ${ }^{1}$, Rubson da Costa Leite ${ }^{2}$, Thalita Rodrigues Silva ${ }^{1}$, Thayny Alves Viana ${ }^{1}$, Tatiane de Sousa Cruz $^{2}$, \\ Guilherme Octávio de Sousa Soares ${ }^{2}$, Robson da Costa Leite ${ }^{3} \&$ Raimundo Laerton de Lima Leite $^{1}$ \\ ${ }^{1}$ Federal Institute of Education, Science and Technology of Tocantins, Araguatins, Tocantins, Brazil \\ ${ }^{2}$ Federal University of Tocantins, Araguaína, Tocantins, Brazil \\ ${ }^{3}$ Federal University of Tocantins, Gurupi, Tocantins, Brazil \\ Correspondence: Rubson da Costa Leite, Federal University of Tocantins, Araguaína, Tocantins, Brazil. Tel: \\ 55-63-999-579-410. E-mail: rubsonif@gmail.com
}

Received: August 24, 2018

doi:10.5539/jas.v10n12p321
Accepted: September 27, $2018 \quad$ Online Published: November 15, 2018

URL: https://doi.org/10.5539/jas.v10n12p321

\begin{abstract}
Among the several factors that may influence nodulation and the efficiency of biological nitrogen fixation for soybean plants, nutrient availability is among the most important. This study aimed to evaluate the inoculation with Bradyrhizobium japonicum and doses of phosphorus on the development of soybean in a Vertisol, in Tocantins. The experimental design was completely randomized in a $4 \times 2$ factorial scheme, with four replications. Four doses of phosphate fertilization $\left(0,100,200\right.$, and $\left.300 \mathrm{~kg} \mathrm{ha}^{-1} \mathrm{P}_{2} \mathrm{O}_{5}\right)$ were studied, combined with two inoculation treatments with Bradyrhizobium japonicum (inoculated and not inoculated). The following variables were evaluated: plant height, stem diameter, nodules per plant, dry mass of nodules, dry mass of plant, dry mass of root, number of pods and number of grains per pod. Under greenhouse conditions and soil with good availability of phosphorus, there is no influence of the doses on the inoculation with Bradyrhizobium japonicum. Soils with good availability of phosphorus have low response to the application of phosphate fertilizer.
\end{abstract}

Keywords: phosphate fertilization, biological fixation of nitrogen, Glycine max

\section{Introduction}

Soybean [Glycine $\max (\mathrm{L})$.$] is among the most important crops grown worldwide (Abou-Shanab et al., 2017;$ Leggett et al., 2017). The main producers of soybean are the United States of America, Brazil, and Argentina (Bellaloui et al., 2017). It represents the main grain in planted area in Brazil, occupying $57 \%$ of the area planted with grains in the country (CONAB, 2018).

Known for its high nitrogen demand $(\mathrm{N})$, soybean needs about $80 \mathrm{~kg}$ of $\mathrm{N}$ to produce $1000 \mathrm{~kg}$ of grains (Kaschuk et al., 2016). In Brazil, the cultivation of this legume occurs without the use of nitrogen fertilizers due to biological nitrogen fixation (BNF) (Hungria \& Mendes, 2015). BNF is performed by bacteria known as rhizobia that form root nodules in symbiosis with plants. Within these nodules, bacteria capture atmospheric nitrogen and reduce forms that are assimilable by plants (Delamuta et al., 2017).

Bradyrhizobium japonicum is the dominant occupant in the nodules of soybean roots. The bacterium association with the plant is symbiotic, where the plant provides energy, carbohydrates and mineral nutrients to the bacteria, and the bacteria in turn use that energy to capture atmospheric nitrogen and make it bioavailable to the plant (Panzieri et al., 2000).

Practices that can optimize biological nitrogen fixation and crop yield are of extreme importance for soybean crop in Brazil (Steiner et al., 2018). Among the many factors that may influence nodulation and the efficiency of BNF for soybean plants, nutrient availability plays an important role (Silva et al., 2010; Zimmer et al., 2016), since the biological nitrogen fixation in soybean is dependent on an adequate supply of macro and micronutrients (Steiner et al., 2018).

Nutrients maximize the symbiotic interaction and support the host plant and its microbial partner (Nelwamondo \& Dakora, 1999). Phosphorus is highly necessary because the symbiosis process $\left(\mathrm{N}_{2}\right.$ fixation) is energy-intensive; it also increases the energetic metabolism, nucleic acid synthesis and membranes, photosynthesis, respiration, 
and enzymatic regulation (Adewoyin et al., 2017). Still important for the establishment of nodulation, this nutrient increases the number of root hairs, providing more infection sites for nitrogen fixing bacteria (Silva et al., 2010).

Studies were conducted to evaluate the effect of phosphorus doses on inoculation of plants in regions such as Ethiopia with chickpeas and soybeans (Abitew \& Kibret, 2017; Wolde-meskel et al., 2018), Brazil with cowpea (Silva et al., 2010), and Ghana with soybean (Adewoyin et al., 2017). Considering this, the present study aimed to evaluate the inoculation with Bradyrhizobium japonicum and doses of phosphorus on soybean production in a Vertisol, in Tocantins state, Brazil.

\section{Material and Methods}

\subsection{Experimental Conditions}

The study was carried out under greenhouse at the Federal Institute of Education, Science and Technology of Tocantins, Campus Araguatins (coordinates UTM: 824304.76 and 9374641.48). The soil used presents clayey texture (sand: $38.1 \%$; silt: $21.3 \%$, and clay: $40.6 \%), \mathrm{pH}\left(\mathrm{CaCl}_{2}\right)=5.6$; $\mathrm{P}$ and $\mathrm{K}($ Mehlich-1) $=30.8$ and $113 \mathrm{mg}$ $\mathrm{kg}^{-1}$, respectively; $\mathrm{Al}^{3+}=0.0 ; \mathrm{Ca}^{2+}$ and $\mathrm{Mg}^{2+}=17.5$ and $4.8 \mathrm{cmol}_{\mathrm{c}} \mathrm{dm}^{-3}$ respectively; $\mathrm{H}^{+}+\mathrm{Al}^{3+}=7.9 \mathrm{cmol}_{\mathrm{c}} \mathrm{dm}^{-3}$; $\mathrm{CEC}=31.0 \mathrm{cmol}_{\mathrm{c}} \mathrm{dm}^{-3}$ and organic matter $=3.4 \mathrm{dag} \mathrm{kg}^{-1}$, being classified as Vertisol (USDA classification system).

\subsection{Experimental Design and Data Collection}

The experimental design was a completely randomized design, in a $4 \times 2$ factorial scheme, totaling eight treatments with four replications. Four doses of phosphate fertilization $\left(0,100,200\right.$, and $\left.300 \mathrm{~kg} \mathrm{ha}^{-1} \mathrm{P}_{2} \mathrm{O}_{5}\right)$ were studied, combined with two inoculation treatments with Bradyrhizobium japonicum (inoculated and not inoculated). Each experimental plot was represented by cylindrical vessels with a capacity of 10 liters.

Phosphate fertilization occurred at the time of sowing of soybean seeds. For the inoculation of soybean seeds commercial peat inoculum ( $60 \mathrm{~g}$ of inoculant to $50 \mathrm{~kg}$ of seeds) was used, which contained Bradyrhizobium japonicum strains (SEMIA 5079 and SEMIA 5080, $5 \times 10^{9}$ viable cells per gram of inoculant). The inoculation was carried out with the previous wetting of the seeds with a solution of cornstarch and water in the proportion of $6 \mathrm{~mL} / \mathrm{kg}$ of seed. The procedure was carried out 6 hours before sowing, in a closed environment with absence of solar incidence.

Glycine max L., cultivar TMG 2179 IPRO, early cycle, was used. Seeding was done manually on April 20th, 2017, with the distribution of 5 seeds per pot, at a depth of $3 \mathrm{~cm}$ in the soil. Subsequently, 15 days after sowing, thinning was performed, and only two plants were conducted until the end of the experiment. The irrigation process was done daily and manually, always maintaining $50 \%$ of field capacity. There was no severe attack of pests and diseases. Weed control was performed manually when necessary.

The analyzed variables were: plant height, stem diameter, nodules per plant, dry mass of nodules, dry mass of plant, dry mass of root, number of pods and number of grains per pod.

Plant height was evaluated using a ruler graduated in centimeters by measuring the distance between the soil surface and the apex of the plant. The stem diameter was evaluated with a digital caliper, measuring the diameter at the height of $3 \mathrm{~cm}$ of the soil, being the result expressed in mm. Number of pods and number of grains per pod were obtained by direct counting. The evaluations of nodules per plant, dry mass of nodules, dry mass of plant, and dry mass of root were carried out at the full flowering stage at 45 days after sowing (period of maximum biological fixation of $\mathrm{N}$ ), with fully developed leaves and some open flowers on the upper knuckles of the main stem. Using a 3-mm mesh sieve and running water, the nodules of each plant were separated from soil and roots and counted manually to obtain nodules per plant, then packed in properly identified paper bags and oven dried at $65^{\circ} \mathrm{C}$ for 72 hours to be weighed in precision scale to obtain the dry mass of nodules. The plants used to count the number of nodules had the shoot and roots separated and, similarly to the nodules per plant, were packed in properly identified paper bags and oven dried at $65^{\circ} \mathrm{C}$ for 72 hours to be weighed for the obtention of the dry mass of plant and dry mass of root.

\subsection{Statistical Analysis}

All data were initially tested for normality by the Shapiro-Wilk method and homoscedasticity. The F test was applied for the qualitative data (inoculation), when these were significant the Tukey test at $5 \%$ probability was applied. For the quantitative data (doses of phosphorus) the regression analysis was performed, evaluating the significance of the betas and the determination coefficients to obtain the appropriate regression model, adopting $5 \%$ probability. 


\section{Results and Discussion}

The results of the analysis of variance showed interaction $(p \leq 0.05)$ between inoculation factors and phosphorus doses for the variables nodules per plant and dry mass of plant (Figures $1 \mathrm{C}$ and $2 \mathrm{~A}$ ). The variables plant height, dry mass of nodules, dry mass of root, number of pods, and grains per pod did not show influence for inoculation with B. japonicum, regardless the supply of phosphorus or not (Figures 1A, 1D, 2B, 2C and 2D).
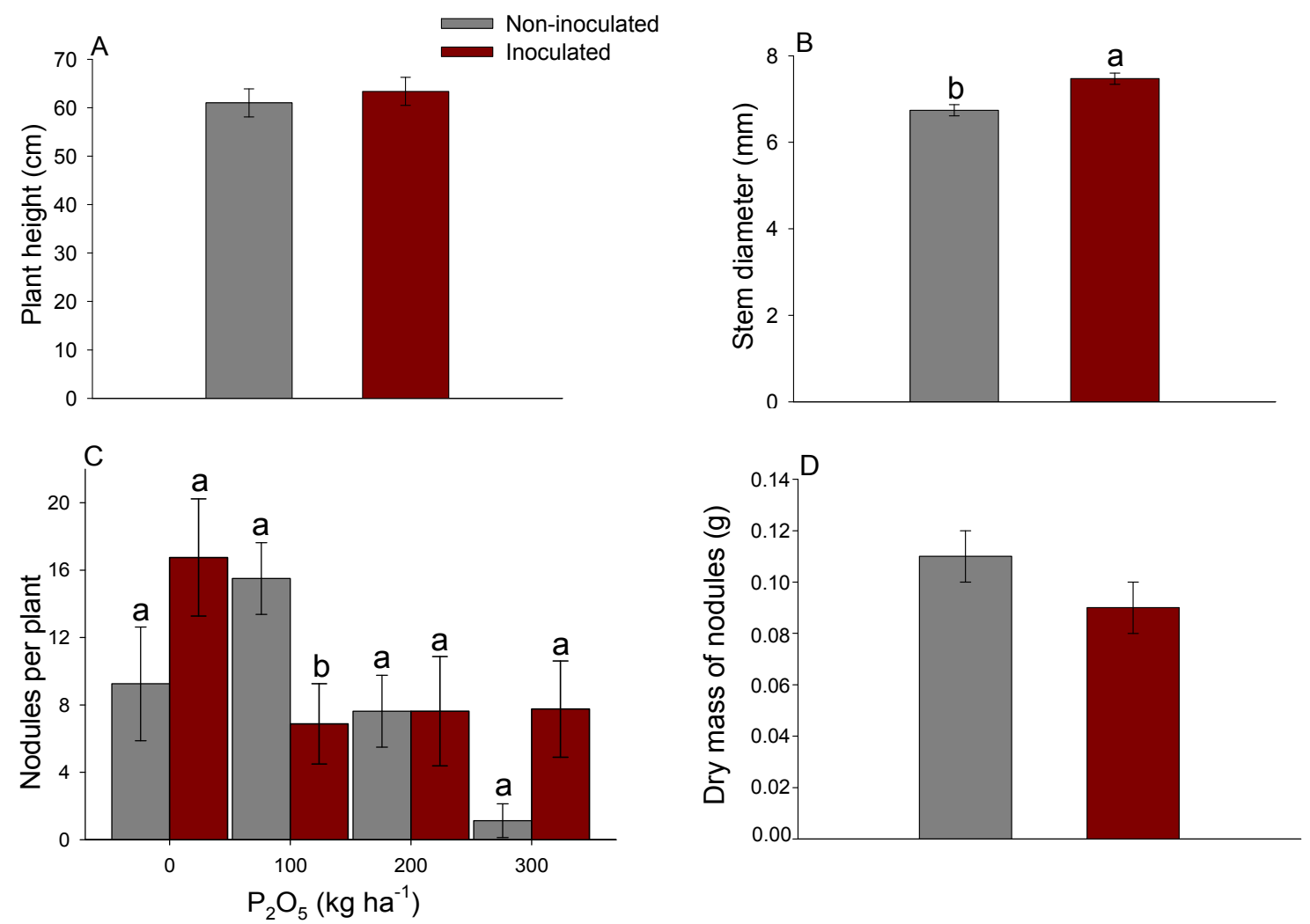

Figure 1. Plant height (A), stem diameter (B), number of nodules (C) and dry mass of nodules (D) of soybean plants as a function of phosphorus doses and inoculation with $B$. japonicum

Note. Averages followed by the same letter do not significantly differ by the Tukey test $(\mathrm{p}<0.05)$.

Plant height did not change as a function of inoculation $(p>0.05)$. Non-inoculated plants presented height of $61.0 \mathrm{~cm}$ and inoculated plants had a height of $63.3 \mathrm{~cm}$ (Figure 1A). The height of plants may not have varied as the plant has restricted its greater development to the diameter characteristic (Figure 1B).

For stem diameter, the plants showed difference in inoculation $(\mathrm{p} \leq 0.05)$ (Figure 1B). The mean diameter of stems for inoculated plants was $7.4 \mathrm{~mm}$, whereas non-inoculated plants presented average of $6.7 \mathrm{~mm}$. These values represent an increase of $10.4 \%$ in the diameter of the plants. This characteristic presents an important function of avoiding problems with lodging, besides promoting a better support of the plant (Oliveira et al., 2014).

In relation to the number of nodules, the response of the plants for inoculation varied as a function of the dose of provided P (Figure 1C). The difference $(\mathrm{p} \leq 0.05)$ occurred only at the dose $100 \mathrm{~kg} \mathrm{ha}^{-1}$ with non-inoculated plants presenting higher number of nodules than inoculated plants. Plant inoculation, at $100 \mathrm{~kg} \mathrm{ha}^{-1}$ dose, promoted nodules per plant reduction of $55.6 \%$. At doses 0,200 , and $300 \mathrm{~kg} \mathrm{ha}^{-1}$, there was no difference $(\mathrm{p}>$ 0.05 ) in the nodules per plant for the inoculation of plants.

Similar to the results of this study, Abitew and Kibret (2017), when studying the combination of B. japonicum, doses of phosphorus and nitrogen, concluded that the combination of bacteria with doses of phosphorus increases the nodulation potential of soybean plants. Bacteria of B. japonicum form a symbiotic relationship with soybean and promote increase in nodulation, which leads to an increase in plant weight (Pawar et al., 2018). 
Although the difference in the number of nodules as a function of the dose of phosphorus supplied to plants was verified, the dry mass of the nodules did not differ in the plants (Figure 1D). Inoculated plants had a dry nodule mass of $0.09 \mathrm{~g}$, whereas the non-inoculated plants presented $0.1 \mathrm{~g}$.

The dry mass of the plants presented difference $(\mathrm{p} \leq 0.05)$ only when no phosphorus was applied to the soil (Fig. 2A). At the zero dose of phosphate fertilizer, non-inoculated plants had a mass of $8.5 \mathrm{~g}, 37.7 \%$ higher than inoculated plants $(6.2 \mathrm{~g})$. When phosphorus was applied to the soil (doses 100, 200, and $300 \mathrm{~kg} \mathrm{ha}^{-1}$ of $\mathrm{P}_{2} \mathrm{O}_{5}$ ), there was no difference $(\mathrm{p}>0.05)$ between inoculated and non-inoculated plants. Differing from these results, Pawar et al. (2018), in a study of co-inoculation of soybean and doses of nitrogen fertilizers and phosphates, found an increase in the dry mass of soybean plants when combined doses of phosphorus with bacteria of $B$. japonicum and Pseudomonas fluorescens. However, the efficiency found in the absence of fertilizer may have been due to the good levels of phosphorus present in the soil used in our study.
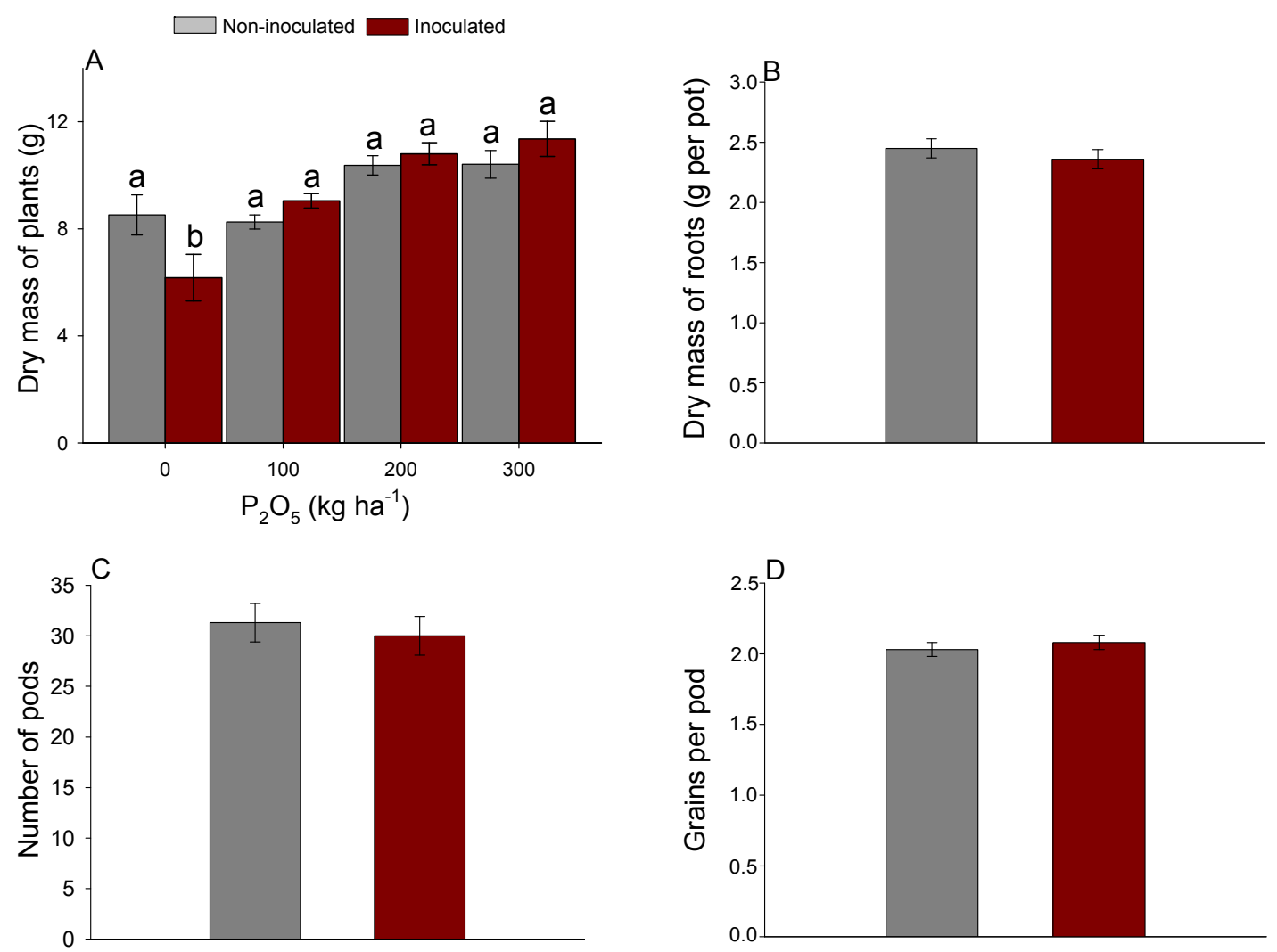

Figure 2. Dry mass of the plant (A), dry mass of the roots (B), number of pods (C) and grain per pod (D) of soybean plants as a function of phosphorus doses and inoculation with $B$. japonicum

Note. Averages followed by the same letter do not significantly differ by the Tukey test $(\mathrm{p}<0.05)$.

The success in the symbiosis between bacteria and plants depends on environmental factors such as the physic-chemical properties of soils, as well as on the Bradyrhizobium strain and the soybean genotype used (Abou-Shanab et al., 2017), not always showing benefits for plants. An important factor to consider is that these bacteria are native to soils, and the inoculation has the advantage of increasing the number of bacteria in the rhizosphere of the plant, which could also be present in the soil where there was no inoculation, thus minimizing the effect between inoculated plants and not inoculated.

Another aspect that may have interfered in the results of this study is the temperature, since the experiment took place in pots, which may have increased the temperature in the rhizosphere of the plant due to the smaller volume of soil and impaired the development of the bacteria. According to Fernandes Júnior and Reis (2008), high temperatures can hinder the performance and development of the bacteria in symbiosis with legumes even in water availability. Araújo et al. (2018) mentioned that in studies conducted in greenhouse or growth chambers 
the intensity of light and temperature may result in plants much smaller than those found in the field due to damage to soil microorganisms.

There was no difference $(\mathrm{p}>0.05)$ between inoculated and non-inoculated plants in relation to root production (Figure 2B). Inoculated plants presented root mass of $2.3 \mathrm{~g}$ while non-inoculated plants presented $2.4 \mathrm{~g}$. Similar to our results, Oliveira et al. (2017) found no influence of inoculation with B. japonicum for the variable root weight. It is noteworthy that the soil used by these authors presented good availability of phosphorus as comparable to our study.

The variables that evaluated the productive capacity of soybean plants (number of pods and grains per pods) did not present difference $(p>0.05)$ for the inoculation (Figures $2 \mathrm{C}$ and $2 \mathrm{D})$. The production of inoculated plant pods was 30.0 pods per plant, whereas non-inoculated plants presented 31.3 pods per plant. Inoculated and non-inoculated plants produced 2.0 grains per pod on average.

Regarding the response of the soybean plants as a function of the doses of phosphorus applied to the soil, only the variables stem diameter, dry mass of plants, and dry mass of the roots presented regression adjustment (Figures 3 and 4). Plant height, number of nodules, dry mass of nodules, number of pods, and grains per pods showed no adjustment to the proposed regression models, regardless of inoculation or not of soybean plants (Figures 3A, 3C, 3D, 4C and 4D). Possibly, the amount of phosphorus already present in the study soil has supplied the nutrient needs of the crop. According to the Cerrado Soil Correction and Fertilization Manual (Sousa \& Lobato, 2004), soils with clay content between 36 and $60 \%$ that present soil P levels above $12 \mathrm{mg} \mathrm{kg}^{-1}$ are high in $\mathrm{P}$ available on the ground.
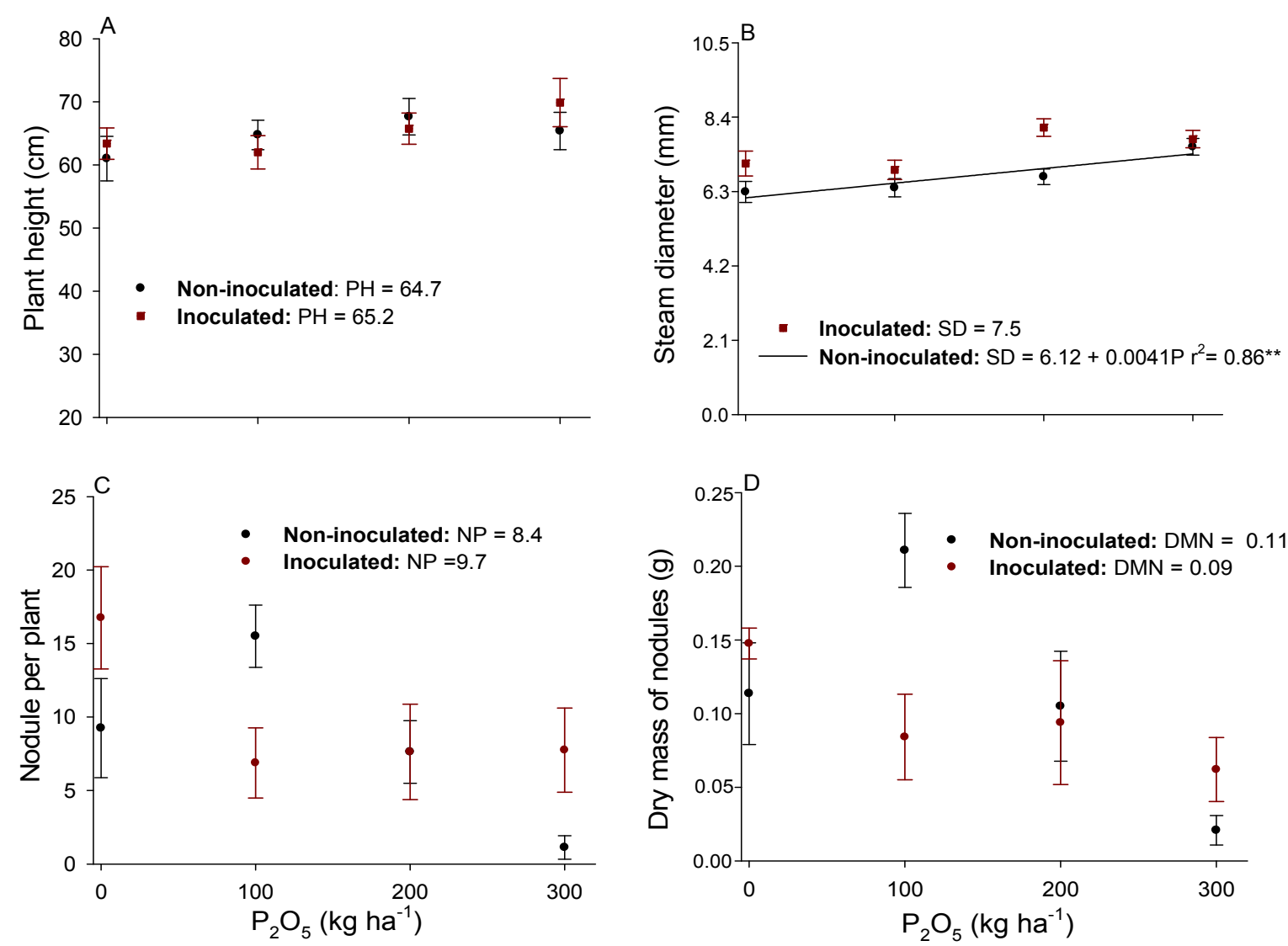

Figure 3. Plant height (A), stem diameter (B), number of nodules (C) and dry mass of nodules (D) in soybean plants (inoculated and non-inoculated) of phosphorus doses

Note. The numbers in the figures indicate the means for variables that did not fit the regression.

When evaluating the production of soybean and corn as a function of fertilization in soil with fertility, Lacerda et al. (2015) verified that there were no significant gains from fertilization in these soils. Specifically, at high levels 
of phosphorus in the soil, these authors stated that in clayey soils as the concentration in the solution decreases due to the absorption by the crops, the release of the adsorbed $\mathrm{P}$ to the solution occurs in order to maintain the equilibrium.

In contrast to these results, where there was no increase in soybean productivity components as a function of phosphate fertilization, Santos et al. (2015) observed increases in plant height and number of pods per plant due to the application of phosphate fertilizer in soil with high availability of this nutrient. However, these authors emphasized the low increase in production (6\%) compared to dose zero (absence of phosphate fertilizer) with the highest dose given $\left(400 \mathrm{~kg} \mathrm{ha}^{-1} \mathrm{P}_{2} \mathrm{O}_{5}\right)$.

Regarding the number of grains per pod, this is a characteristic of high genetic heritability, being influenced by the environment only in environmental situations highly restrictive to the good development of the crop (Schoninger et al., 2015; Leite et al., 2017). As our study was conducted under controlled conditions and the soil showed good P availability, there were no restrictive environmental situations even at the zero dose of phosphate fertilizer.

For the stem diameter only, non-inoculated plants showed adjustment to the linear model (Figure 3B). In the absence of phosphate fertilization, plants presented $6.12 \mathrm{~mm}$ of diameter; with fertilization there was an increment of $0.004 \mathrm{~mm}$ to each $\mathrm{kg} \mathrm{ha}^{-1}$ of $\mathrm{P}_{2} \mathrm{O}_{5}$ applied to the soil. The maximum productivity was found in the dose of $300 \mathrm{~kg} \mathrm{ha}^{-1}$ of $\mathrm{P}_{2} \mathrm{O}_{5}$ applied, with stem diameter of $7.32 \mathrm{~mm}$. Inoculated plants had mean stem diameter of $7.5 \mathrm{~mm}$. Oliveira et al. (2014) observed higher stem diameter of bean plants when submitted to doses of phosphorus.

Regarding the dry mass of the plants, inoculated plants presented an adjustment to the quadratic model (Figure 4A). The maximum aerial part production was found in the dose of $258.6 \mathrm{~kg} \mathrm{ha}^{-1}$ of $\mathrm{P}_{2} \mathrm{O}_{5}$, producing a mass of $10 \mathrm{~g}$ per vessel. non-inoculated plants did not fit the regression model, with a mean yield of $9.4 \mathrm{~g}$ per pot.
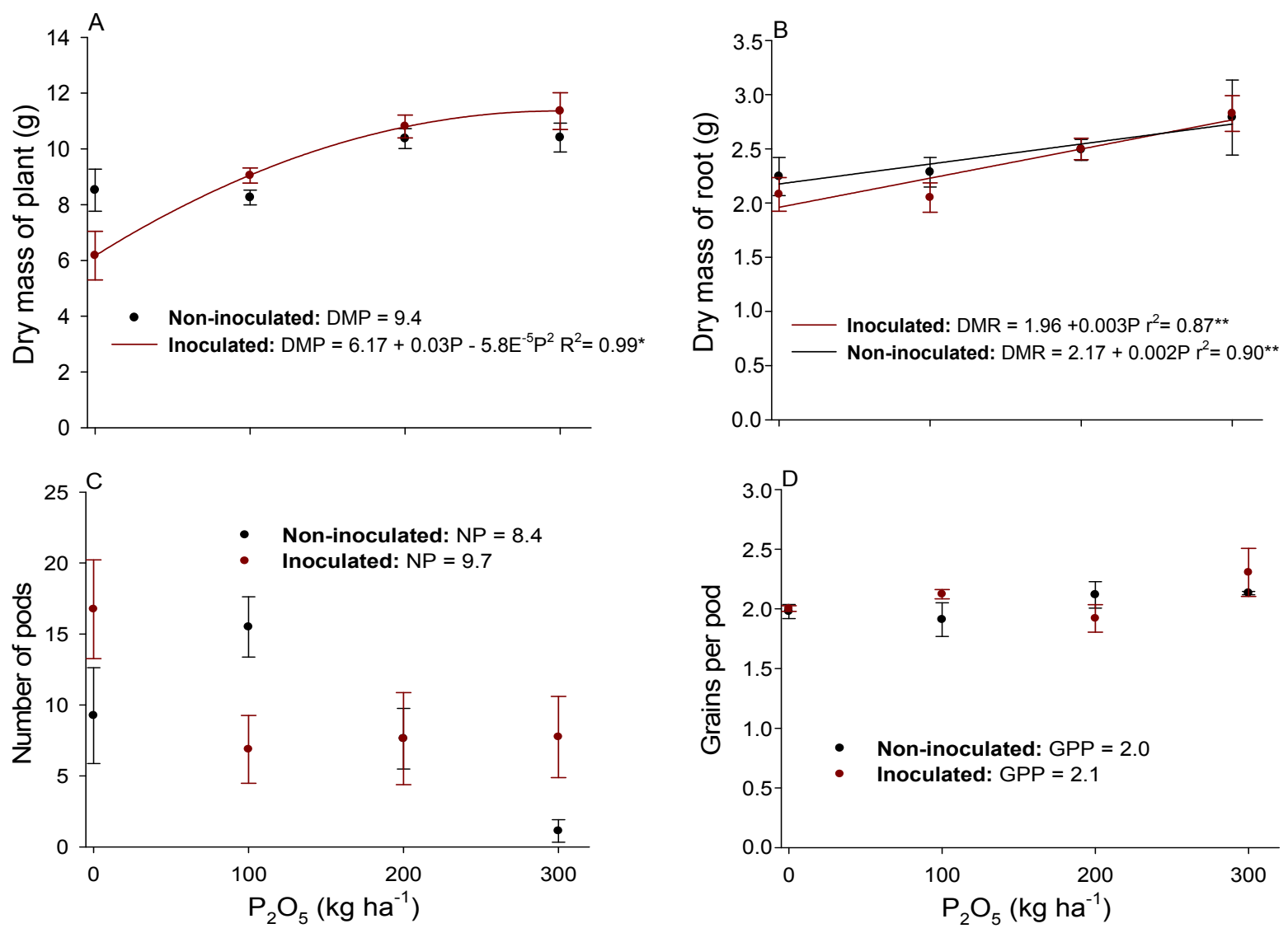

Figure 4. Dry mass of the plants (A), dry mass of roots (B), number of pods (C) and grains per pod (D) of soybean plants (inoculated and non-inoculated) as a function of phosphorus doses

Note. The numbers in the figures indicate the means for variables that did not fit the regression. 
For the dry mass of the roots, plants showed an adjustment to the linear model (inoculated and not inoculated) (Figure 4B). Inoculated plants produced 1.96 grams in the absence of phosphate fertilization, with an increase of $0.003 \mathrm{~g}$ for each $\mathrm{kg} \mathrm{ha}^{-1}$ of $\mathrm{P}_{2} \mathrm{O}_{5}$ applied to the soil. Plants that did not receive the inoculation had similar behavior, with $2.17 \mathrm{~g}$ in root mass in the absence of phosphate fertilization and addition of $0.002 \mathrm{~g} \mathrm{to} \mathrm{kg} \mathrm{ha}^{-1}$ of $\mathrm{P}_{2} \mathrm{O}_{5}$ applied to the soil.

\section{Conclusions}

Under greenhouse conditions and soil with good availability of phosphorus, there is no influence of phosphate doses on inoculation with $B$. japonicum.

Soils with good availability of phosphorus have low response to the application of phosphate fertilizer.

\section{References}

Abitew, M., \& Kibret, K. (2017). Effects of Bradyrhizobium japonicum, nitrogen and phosphorus fertilizers on growth, nodulation, yield and yield components of soybean at pawed northwestern Ethiopia. World Journal of Agricultural Sciences, 13, 53-62.

Abou-Shanab, R. A. I., Wongphatcharachai, M., Sheaffer, C. C., Orf, J. C., \& Sadowsky, M. J. S. (2017). Competition between introduced Bradyrhizobium japonicum strains and indigenous bradyrhizobia in Minnesota organic farming systems. Symbiosis, 73, 155-163. https://doi.org/10.1007/s13199-017-0505-4

Adewoyin, D. T. E., Mensah, N. E., Oluwafemi, O. A., Ogunleti, D., Adekunle, A., \& Kayode, C. (2017). Nodulation, growth and yield response of soybean [(Glycine max L. (Merril)] to inoculum (Bradyrhizobium japonicum) under phosphorus levels and compost amendment in Northern Ghana. Net Journal of Agricultural Science, 5, 141-150. https://doi.org/10.30918/NJAS.54.17.056

Alvares, C. A., Stape, J. L., Sentelhas, P. C., Gonçalves, J. L. De M., \& Sparovek, G. (2013). Köppen's climate classification map for Brazil. Meteorologische Zeitschrift, 22, 711-728. https://doi.org/10.1127/0941-2948/ 2013/0507

Araujo, K. E. C., Vergara, C., Guimarães, A. P., Rouws, J. R. C., Jantalia, C. P., Urquiaga, S., Alves, B. J. R., \& Boddey, R. M. (2018). Changes in ${ }^{15} \mathrm{~N}$ natural abundance of biologically fixed $\mathrm{N}_{2}$ in soybean due to shading, rhizobium strain and plant growth stage. Plant and Soil, 428, 413-428. https://oi.org/10.1007/s11104018-3627-4

Bellaloui, N., Smith, J. R., \& Mengistu, A. (2017). Seed nutrition and quality, seed coat boron and lignin are influenced by delayed harvest in exotically-derived soybean breeding lines under high heat. Frontiers in Plant Science, 8. https://doi.org/10.3389/fpls.2017.01563

Brandelero, E. M., Peixoto, P. C., \& Ralish, R. (2009). Nodulação de cultivares de soja e seus efeitos nos rendimentos de grãos. Semina: Ciências Agrárias, 30, 581-588. https://doi.org/10.5433/1679-0359.2009v30 n3p581

CONAB (Companhia Nacional de Abastecimento). (2018). Acompanhamento da safra brasileira de grãos (p. 178, Safra 2017/2018.5).

Delamuta, J. R. M., Menna, P., Ribeiro, R. A., \& Hungria, M. (2017). Phylogenies of symbiotic genes of Bradyrhizobium symbionts of legumes of economic and environmental importance in Brazil support the definition of the new symbiovars pachyrhizi and sojae, Systematic and Applied Microbiology, 40, 264-265. https://doi.org/10.1016/j.syapm.2017.04.005

EMBRAPA (Empresa Brasileira de Pesquisa Agropecuária). (2013). Centro Nacional de Pesquisa de Solos. Sistema brasileiro de classificação de solos (3rd ed., p. 353). Brasília: Embrapa.

Fernandes Júnior, P. I., \& Reis, V. M. (2008). Algumas limitações a Fixação Biológica de Nitrogênio em leguminosas (p. 33). Embrapa Agrobiologia.

Hungria, M., \& Mendes, I. C. (2015). Nitrogen Fixation with Soybean: The Perfect Symbiosis? In F. J. Bruijn (Ed.), Biological Nitrogen Fixation (Vol. 2, pp. 1009-1023). John Wiley \& Sons. https://doi.org/10.1002/ 9781119053095.ch99

Kaschuka, G., Nogueira, M. A., Luca, M. J., \& Hungria, M. (2016). Response of determinate and indeterminate soybean cultivars to basal and topdressing $\mathrm{N}$ fertilization compared to sole inoculation with Bradyrhizobium. Field Crops Research, 195, 21-27. https://doi.org/10.1016/j.fcr.2016.05.010 
Lacerda, J. J. J., Resende, A. V., Furtini Neto, A. E., Hickmann, C., \& Conceição, O. P. (2015). Adubação, produtividade e rentabilidade da rotação entre soja e milho em solo com fertilidade construída. Pesquisa Agropecuária Brasileira, 50, 769-778. https://doi.org/10.1590/S0100-204X2015000900005

Leggett, M., Diaz-Zorita, M., Koivunen, M., Bowman, R., Pesek, R., Stevenson, C., \& Leister, T. (2017). Soybean Response to Inoculation with Bradyrhizobium japonicum in the United States and Argentina. Agronomy Journal, 109, 1031-1038. https://doi.org/10.2134/agronj2016.04.0214

Leite, R. C., Carneiro, J. S. S., Freitas, G. A., Casali, M. E., \& Silva, R. R. (2017). Adubação fosfatada na soja durante três safras consecutivas na nova fronteira agrícola brasileira. Scientia Agraria, 18, 28-35. https://doi.org/10.5380/rsa.v18i4.50310

Oliveira, J. G., Silva, V. S. G., \& Costa, J. P. V. (2017). Comportamento de soja submetida a materiais fertilizantes e inoculação com Bradyrhizobium. Revista da Universidade Vale do Rio Verde, 15, 66-72. https://doi.org/10.5892/ruvrd.v15i1.3016

Oliveira, T. C., Silva, J., Santos, M. M., Cancellier, E. L., \& Fidelis, R. R. (2014). Desempenho agronômico de cultivares de feijão em função da adubação fosfatada no sul do estado do Tocantins. Revista Caatinga, 27, 50-59.

Panzieri, M., Marchettini, N., \& Hallam, T. G. (2000). Importance of the Bradyrhizobium japonicum symbiosis for the sustainability of a soybean cultivation. Ecological Modelling, 135, 301-310. https://doi.org/10.1016/ S0304-3800(00)00383-5

Pawar, P. U., Kumbhar, C. T., Patil, V. S., \& Khot, G. G. (2018). Effect of co-inoculation of Bradyrhizobium japonicum and Pseudomonas fluorescens on growth, yield and nutrient uptake in soybean [Glycine max (L.) Merrill]. Crop Research, 53, 57-62. https://doi.org/10.5958/2454-1761.2018.00009.8

Santos, A. C. M., Carneiro, J. S. S., Leite, R. C., Souza, M. A. S., Freitas, G. A., \& Silva, R. R. (2015). Adubação fosfatada com fertilizante Basiduo ${ }^{\circledR}$ na cultura da soja no oeste da Bahia. Journal of Bioenergy and Food Science, 2, 82-90. https://doi.org/10.18067/jbfs.v2i3.25

Schoninger, E. L., Lange, A., Menegon, T. G., \& Caione, G. (2015). Grain yield of bean as affected by phosphorus and nitrogen rates. Agrarian, 8, 387-398.

Silva, E. F. L., Araújo, A. S. F., Santos, V. B., Nunes, L. A. P. L., \& Carneiro, R. F. V. (2010). Fixação biológica do $\mathrm{N}_{2}$ em feijão-caupi sob diferentes doses e fontes de fósforo solúvel. Bioscience Journal, 26, 394-402.

Sousa, D. M. G., \& Lobato, E. (2004). Cerrado: Correção do solo e adubação (p. 416). Brasília: Embrapa Informação Tecnológica.

Steiner, F., Zuffo, A. M., Bush, A., \& Santos, D. M. S. (2018). Silicate fertilization potentiates the nodule formation and symbiotic nitrogen fixation in soybean. Pesquisa Agropecuária Tropical, 48, 212-221.

Wolde-Meskela, E., Heerwaarden, J. V., Abdulkadir, B., Kassa, S., Aliyi, I., Degefu, T., ... Giller, K. E. (2018). Additive yield response of chickpea (Cicer arietinum L.) to rhizobium inoculation and phosphorus fertilizer across smallholder farms in Ethiopia. Agriculture, Ecosystems and Environment, 261, 144-152. https://doi.org/10.1016/j.agee.2018.01.035

Zimmer, S., Messmer, M., Haase, T., Piepho, H. P., Mindermann, A., Schulz, H., ... Heb, J. (2016). Effects of soybean variety and Bradyrhizobium strains on yield, protein content and biological nitrogen fixation under cool growing conditions in Germany. European Journal Agronomy, 72, 38-46. https://doi.org/10.1016/j.eja. 2015.09.008

\section{Copyrights}

Copyright for this article is retained by the author(s), with first publication rights granted to the journal.

This is an open-access article distributed under the terms and conditions of the Creative Commons Attribution license (http://creativecommons.org/licenses/by/4.0/). 